Tersedia online di: http://ejournal-balitbang.kkp.go.id/index.php/bawal
e-mail:bawal.puslitbangkan@gmail.com
BAWAL wIDYA RISET PERIKANAN TANGKAP
Volume 9 Nomor 3 Desember 2017
e-ISSN: 2502-6410
NAWALr Akreditasi: 620/AU2/P2MI-LIPI/03/2015

\title{
ESTIMASI PARAMETER POPULASI IKAN CAKALANG (Katsuwonus pelamis, Linnaeus, 1758) DI PERAIRAN SAMUDRA HINDIA
}

\section{POPULATION PARAMETERS ESTIMATION OF SKIPJACK TUNA (Katsuwonus pelamis, Linnaeus, 1758) IN INDIAN OCEAN}

\author{
Raymon R. Zedta ${ }^{1}$, Prawira ARP Tampubolon ${ }^{1}$ dan Dian Novianto ${ }^{1}$ \\ ${ }^{1}$ Loka Penelitian Perikanan Tuna, Denpasar \\ Jl. Mertasari No. 140 Br Suwung Kangin, Sidakarya, Denpasar Bali, 80224 \\ Teregistrasi I tanggal: 05 April 2017; Diterima setelah perbaikan tanggal: 19 Desember 2017; \\ Disetujui terbit tanggal: 29 Desember 2017
}

\begin{abstract}
ABSTRAK
Penelitian ini bertujuan untuk mengkaji parameter populasi ikan cakalang (Katsuwonus pelamis) yang tertangkap pukat cincin di WPP-572 Samudra Hindia Barat Sumatera dan WPP-573 Selatan Jawa. Hasil penelitian ini diharapkan dapat digunakan sebagai masukan dalam penentuan pengelolaan perikanan sehingga stok ikan cakalang dapat dimanfaatkan secara berkelanjutan. Ikan contoh dikumpulkan melalui program enumerasi tahun 2016 (Januari-Desember). Sampling acak dilaksanakan di empat pelabuhan, yaitu PPS Lampulo (Aceh), PPN Sibolga (Sumatra Utara), PPP Tamperan (Pacitan) dan IPP Pondokdadap (Malang). Jumlah ikan contoh diperoleh sebanyak 14.894 ekor. Serial data fekuensi panjang bulanan diolah menggunakan program FiSAT II untuk menduga parameter pertumbuhan, mortalitas dan tingkat eksploitasi. Hasil penelitian menunjukkan ikan cakalang yang tertangkap di WPP-572 memiliki panjang asimtotik $\left(\mathrm{L}_{\infty}\right) 73,5 \mathrm{cmFL}, \mathrm{K}$ sebesar $0.22 /$ tahun dan $\mathrm{t}_{\mathrm{o}}$ sebesar $-0,59$ tahun. Parameter populasi di WPP-573 berturut-turut $\mathrm{L}_{n}=67,20 \mathrm{cmFL}, \mathrm{K}=0,27 / \mathrm{tahun}$, dan $\mathrm{t}_{\mathrm{o}}=-0,50$ tahun. Nilai mortalitas alami (M) ikan cakalang di WPP 572 sebesar 0,49/tahun, mortalitas total (Z) 0,70/tahun, dan kematian akibat penangkapan (F) adalah 0,21/tahun. Ikan cakalang yang tertangkap di WPP 573 menunjukkan nilai (E) sebesar 0,59/tahun, nilai Z 1,02/tahun, dan nilai F sebesar 0,43/tahun. Dugaan tingkat eksploitasi ikan cakalang di WPP 572 dan 573 masing-masing 0,3/tahun dan 0,42/tahun atau belum berada pada tahap optimal.
\end{abstract}

Kata Kunci: Parameter populasi; Cakalang; Samudra Hindia

\begin{abstract}
This study aimed to assess the population parameters of skipjack tuna (Katsuwonus pelamis) that caught by purse seine in the Indonesian FMA (Fisheries Management Area) 572 Indian Ocean West Sumatera and FMA 573 South Java. The outcomes of this research can hopefully be used as inputs for fisheries management, in order the stock of skipjack tuna can be utilized sustainably. Fish sample were collected through the program enumeration of Research Institute for Tuna Fisheries (RITF) during the year 2016 (Januari-Desember). Using random sampling method at four fishing ports, namely PPS Lampulo (Aceh), PPN Sibolga (North Sumatra), PPP Tamperan (Pacitan), and IPP Pondokdadap (Malang). The total number of fish samples was 14.894 fish. Monthly length frequency data processed using FiSAT II program to estimate the growth parameters, mortality, and exploitation. The analysis results showed that skipjack tuna caught in FMA 572 has asymtotic length value $\left(L_{\infty}\right)$ at $73.5 \mathrm{cmFL}, K$ value 0.22/year, and to at -0.59 year; while in FMA 573 population parameters values respectively $67.20 \mathrm{cmFL}, 0.27 /$ year, and -0.50 year. The value of natural mortality $(M)$ skipjack in FMA 572 is $0.49 /$ year, total mortality $(Z) 0.70 /$ year, and fishing mortality $(F) 0.21 /$ year. Skipjack tuna that caught in FMA 573 showed value of $M 0.59 /$ year, $Z$ value 1.02/year, and $F$ value 0.43/year. The estimated values of exploitation levels of skipjack in FMA 572 and 573 were 0.3/year and 0.42/year respectively.
\end{abstract}

Keywords: Population parameters; skipjack tuna; Indian Ocean 


\section{PENDAHULUAN}

Perairan Samudra Hindia barat Sumatra termasuk Wilayah Pengelolaan Perikanan (WPP)-572 dan perairan Selatan Jawa termasuk Wilayah Pengelolaan Perikanan (WPP)-573. Berbagai jenis ikan pelagis besar hasil tangkapan pukat cincin di perairan ini didaratkan di beberapa lokasi pendaratan utama seperti di Lampulo dan Sibolga (Barat Sumatera) serta di Tamperan dan Pondokdadap Malang (selatan Jawa).

Alat tangkap utama yang digunakan untuk menangkap ikan cakalang (Katsuwonus pelamis) dan madidihang (Thunnus albacares) adalah pukat cincin. Total hasil tangkapan ikan tuna oleh armada pukat cincin, sekitar $63 \%$ atau 4,5 juta ton per tahun (ISSF, 2015). Tingkat pemanfaatan cakalang di Samudra Hindia pada tahun 2013 adalah 170.344 ton (Anonimus, 2015). Pada tahun 2003 kapal pukat cincin di PPN Sibolga didominasi oleh kapal besar berukuran antara 50-130 GT (85\% dari jumlah armada pukat cincin) kapal berukuran lebih kecil (20-49 GT) sebanyak 15\% (Hariati, 2011).

Ikan cakalang yang sebagian besar hidupnya berada di perairan neretik (perairan dangkal), diduga memiliki populasi berbeda antara ikan yang tertangkap di Barat Sumatera dan Selatan Jawa.

Pada tahun 2013 produksi ikan cakalang yang tertangkap pukat cincin menempati urutan pertama di PPN Sibolga yaitu 9.406,5 ton atau 64,5\% dari total tangkapan. Penangkapan dilakukan di rumpon yang dipasang di sekitar Pulau Enggano, Mentawai, Nias sampai perairan barat Aceh (Anonimus, 2012).

Penangkapan cakalang di Samudra Hindia terus meningkat secara perlahan-lahan dari tahun 1950 sampai 2013. Pada tahun 1950 produksi ikan cakalang di Samudra
Hindia sebesar 15.000 ton dan tahun 2013 sudah mencapai 420.000 ton (Rochman et al., 2015). Indonesia dikenal sebagai salah satu dari 10 negara penghasil tuna dan sejenisnya terbesar di dunia dengan estimasi produksi sebesar 620.000 ton pada tahun 2014 (Wibowo et al., 2016). Sebesar $40 \%$ dari produksi tersebut ditangkap dengan pukat cincin, $60 \%$ lainnya oleh rawai tuna, tonda dan jaring insang yang beroperasi di kawasan Samudra Pasifik barat dan Samudra Hindia.

Tujuan penelitian ini adalah untuk memberikan informasi parameter populasi ikan cakalang di perairan Samudra Hindia barat Sumatra dan selatan Jawa yang tertangkap pukat cincin. Informasi ini penting dan sangat diperlukan untuk menentukan kebijakan pengelolaan sumberdaya ikan maupun perkembangan perikanan tuna selanjutnya.

\section{BAHANDANMETODE}

Ikan contoh dikumpulkan melalui program enumerasi oleh Loka Penelitian Perikanan Tuna (LP2T) mulai JanuariDesember 2016 melalui sampling acak di empat pelabuhan, yaitu PPS Lampulo Aceh, PPN Sibolga Sumatra Utara, PPP Tamperan Pacitan, IPP Pondokdadap Malang (Gambar 1). Sampling dilakukan dengan bantuan enumerator yang telah berkerja sama dengan Loka Penelitian Perikanan Tuna Benoa. Sampling dilakukan setiap hari di kapal yang sedang bongkar, selama satu tahun. Jumlah ikan yang ditargetkan dalam sampling antara 300-350 ekor dalam satu bulan. Pengukuran panjang ikan menggunakan jangka sorong yang terbuat dari alumunium dengan panjang 1,5 meter (ketelitian 1,0 cm). Pengukuran bobot ikan menggunakan timbangan dengan kapasitas 6000 gram dan ketelitian 1 gram. Serial data length-frequency yang diperoleh selama satu tahun kemudian disusun menurut bulan dan kelas panjang dengan menggunakan program excel 2010. Analisis data frekuensi panjang digunakan program ELEFANI.

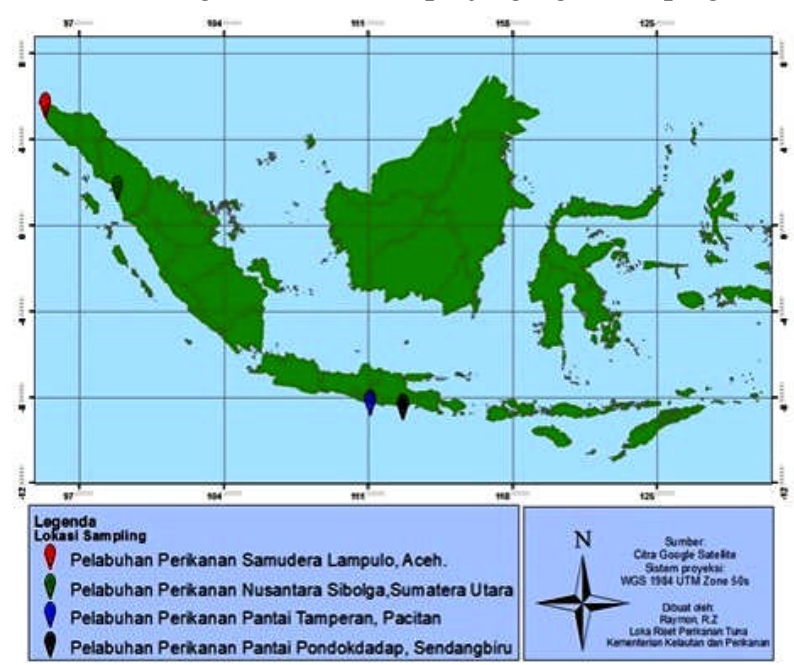

Gambar 1. Peta menunjukkan lokasi sampling di Samudera Hindia.

Figure 1. Map showing sampling sites in Indan Ocean. 
Pengambilan data dilakukan saat ada kapal pukat cincin yang bongkar ikan. Data panjang ikan yang diperoleh kemudian ditabulasikan dalam bentuk tabel distribusi frekuensi panjang dengan interval $2 \mathrm{~cm}$.

Parameter pertumbuhan ikan $\left(\mathrm{K} \& \mathrm{~L}_{\infty}\right.$ ) diestimasi menggunakan perangkat lunak ELEFAN I (Gayanilo et al., 2005) berdasarkan persamaan pertumbuhan Von Bertalanfy (Spare \& Venema, 1999; Effendie, 2002) sebagai berikut :

$\mathrm{L}_{\mathrm{t}}=\mathrm{L} \propto\left[1-\mathrm{e}^{-\mathrm{K}\left(\mathrm{t}-\mathrm{t}_{0}\right)}\right]$

dimana;

$\mathrm{Lt}=$ panjang teoritis ikan pada saat umur tertentu

$\mathrm{L}_{\infty}=$ panjang asimtotik

$\mathrm{K}=$ koefisien pertumbuhan

$\mathrm{T}=$ umur teoritis ikan

$\mathrm{t}_{0}=$ umur teoritis ikan pada saat panjang ke nol

Umur teoritis $\left(\mathrm{t}_{0}\right)$ dihitung menggunakan persamaan empiris Pauly (1983) sebagai berikut:

$\log -\left(t_{0}\right)=-0,3922-0,2752 \log -1,038 \log K$

Nilai M diduga dengan menggunakan rumus empiris Pauly (1983) sebagai berikut:

$\log M=-0,0066-0,279 \operatorname{LogL}-i n f+0,654 \log \mathrm{K}+0,4534$ $\log \mathrm{T}$.

dimana;

$\mathrm{M}=$ laju kematian alamiah

$\mathrm{L}=$ panjang cagak ikan maksimum $(\mathrm{cm})$

$\mathrm{K}=$ laju pertumbuhan ( $\mathrm{cm} /$ tahun)

$\mathrm{T}=$ suhu rata-rata perairan $\left({ }^{\circ} \mathrm{C}\right)$

Nilai Z diduga melalui kurva konversi hasil tangkapan (length vertical catch curve) yang menggunakan slope (b), Ln N/t dan umur relatif sesuai dengan rumus Pauly,(1983) \& Gayanilo et al., (2005) sebagai berikut:

$\operatorname{Ln} \mathrm{N} / \mathrm{t}=\mathrm{a}-\mathrm{Zt}$.

dimana;

$\mathrm{N}=$ banyaknya ikan cakalang pada waktu ke- $\mathrm{t}$

$\mathrm{t}=$ waktu yang diperlukan untuk tumbuh pada suatu kelas panjang

$\mathrm{a}=$ hasil tangkapan yang dikonversikan terhadap panjang

$\mathrm{Z}=$ mortalitas total

Nilai $\mathrm{F}$ diperoleh dari $\mathrm{F}=\mathrm{Z}-\mathrm{M}$; nilai $\mathrm{E}$ dihitung dari $\mathrm{E}=$ F/Z (Sparre \& Venema, 1999). Ukuran panjang rata-rata tertangkap $(\mathrm{Lc}=\mathrm{L} 50 \%)$ didapatkan dengan cara memplotkan frekuensi kumulatif dengan panjang cagak ikan, sehingga akan diperoleh kurva logistik baku; titik potong kurva dengan $50 \%$ frekuensi kumulatif menunjukkan panjang rata-rata ikan tertangkap.

Pendugaan pola pertumbuhan menggunakan program FiSAT dengan input data $\mathrm{L}_{\infty}, \mathrm{K}$, dan $\mathrm{t}_{\mathrm{o}}$ (Gayanilo et al., 2005). Pola rekruitmen menunjukkan pola terjadinya penambahan baru (recruiment) "relatif" dari spesies tertentu dalam setahun.

\section{HASIL DAN BAHASAN \\ Hasil}

\section{Struktur Ukuran dan Rata-Rata Panjang Ikan Tertangkap}

Pengukuran panjang cagak ikan cakalang secara acak di tempat pendaratan ikan dilakukan terhadap 5.923 ekor ikan dengan panjang cagak berkisar antara 20-64 cmFL untuk ikan yang tertangkap di WPP-573 (Pacitan dan Sendang Biru) dan sebanyak 10.524 ekor di WPP-572 (Lampulo dan Sibolga) dengan panjang cagak berkisar antara 18-70 cmFL (Gambar 2 dan 3). 


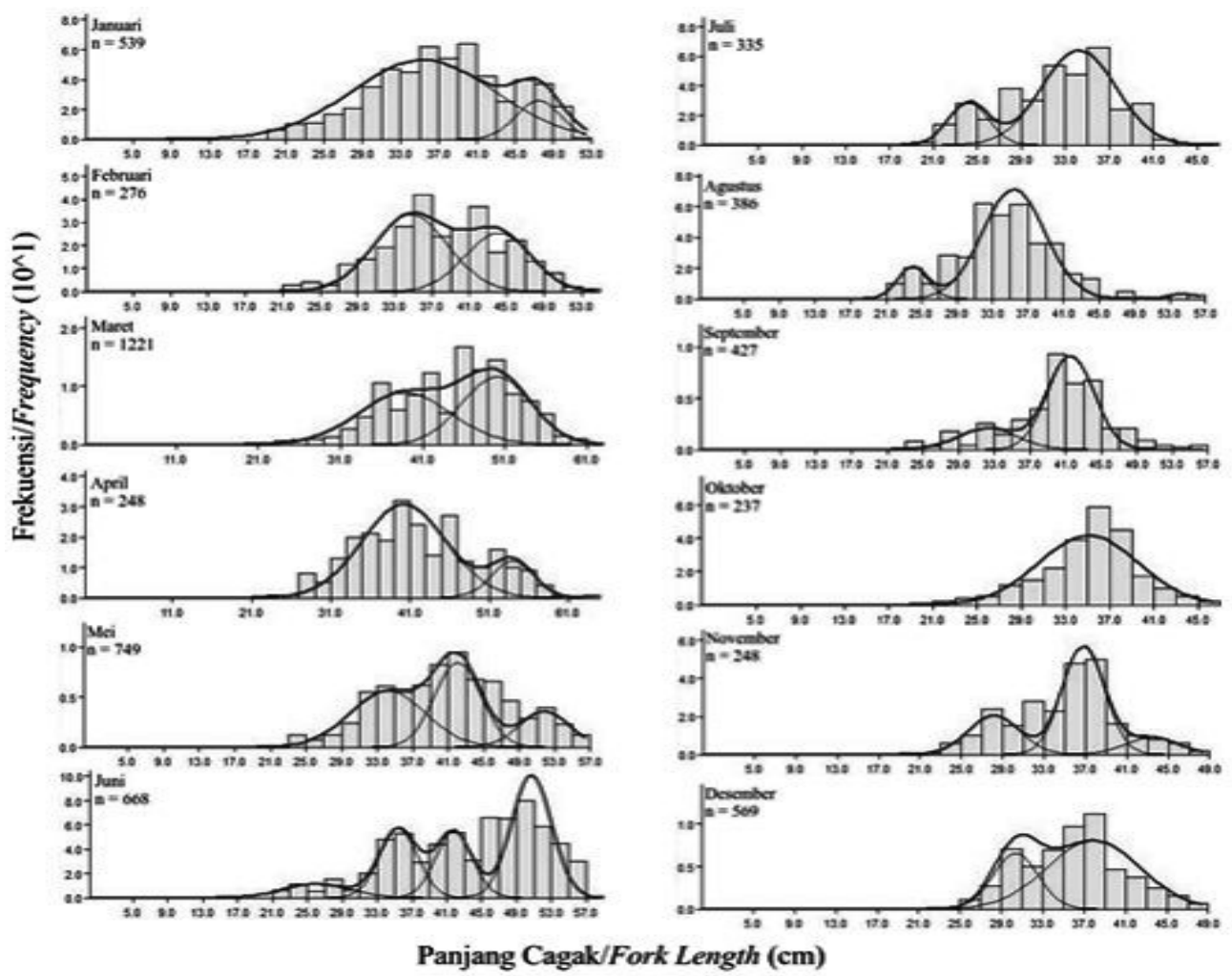

Gambar 2. Distribusi bulanan panjang cagak ikan cakalang yang tertangkap di Samudera Hindia Selatan Jawa. Figure 2. Monthly length-frequency distribution (FL) of skipjack caught in Indian Ocean South of Java

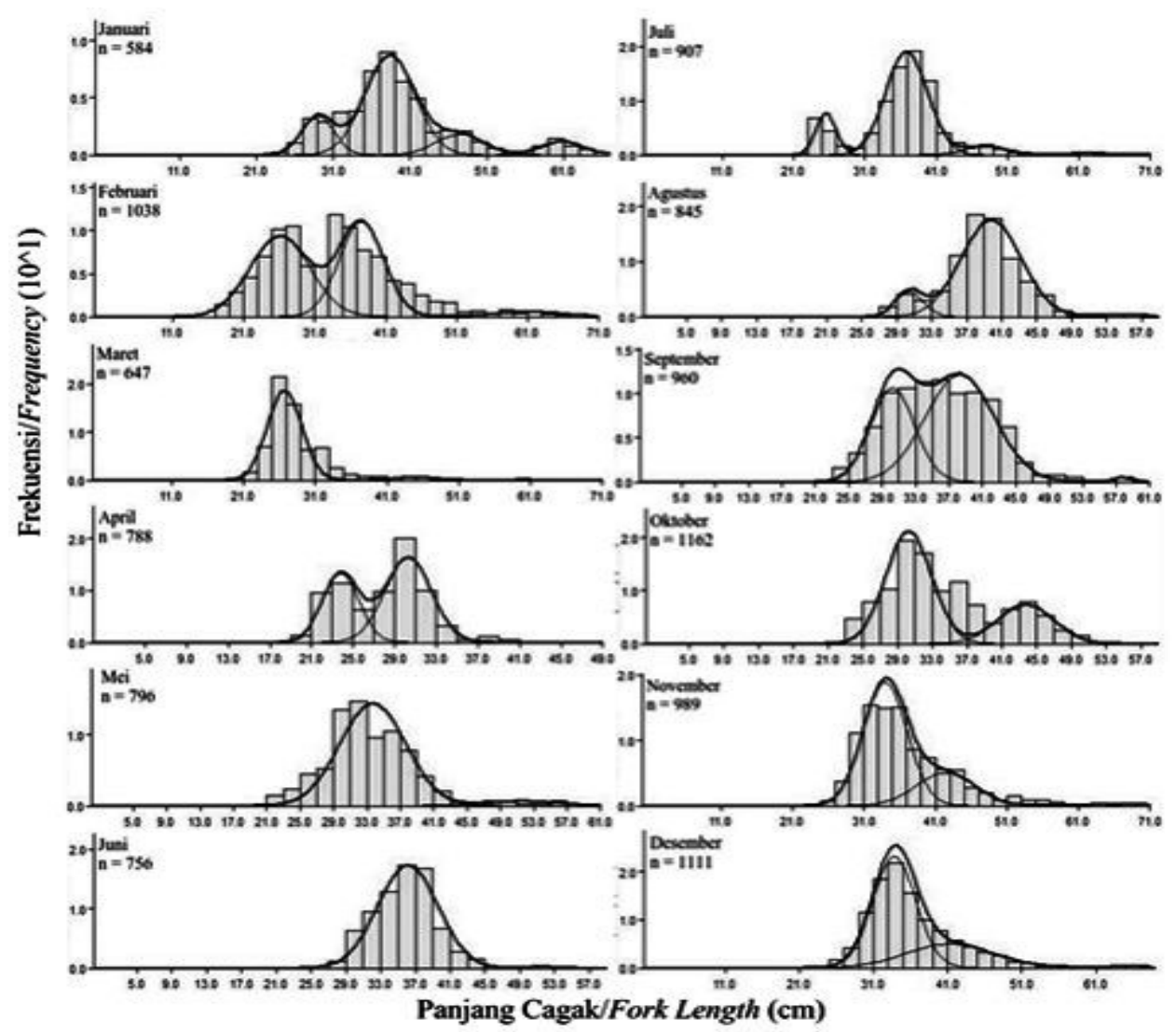

Gambar 3. Distribusi bulanan panjang cagak ikan cakalang yang tertangkap di Samudera Hindia Barat Sumatera. Figure 3. Monthly length-frequency distribution (FL) of skipjack caught in Indian Ocean West of Sumatera. 
Gambar 2 memperlihatkan adanya pergerakan struktur panjang ikan cakalang, kearah kanan pada Januari sampai Juni. Pergerakan tersebut menunjukkan bahwa populasi ikan cakalang yang tertangkap di WPP-573 mengalami pertumbuhan, dan terdapat kelompok-kelompok umur kecil

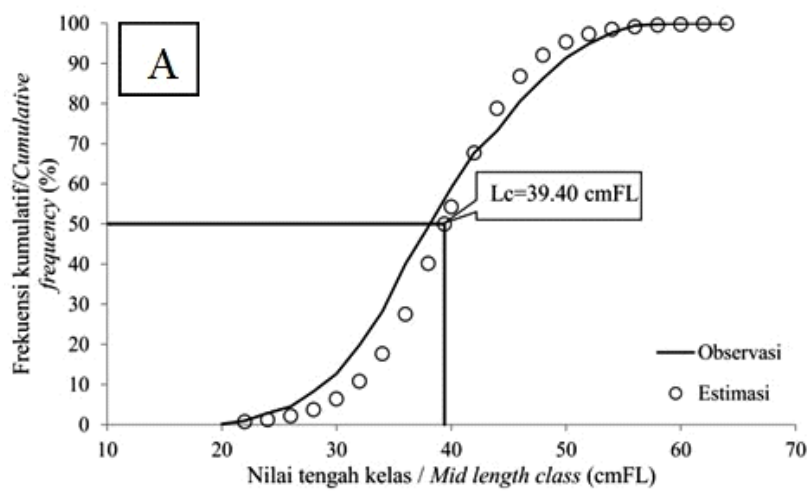

pada Januari - Maret (Tabel. 3) Sedangkan pada Gambar 3. pergerakan ukuran panjang cakalang terjadi pada bulan April sampai September, dan terdapat kelompok umur kecil pada Juli - Agustus (Tabel. 4)

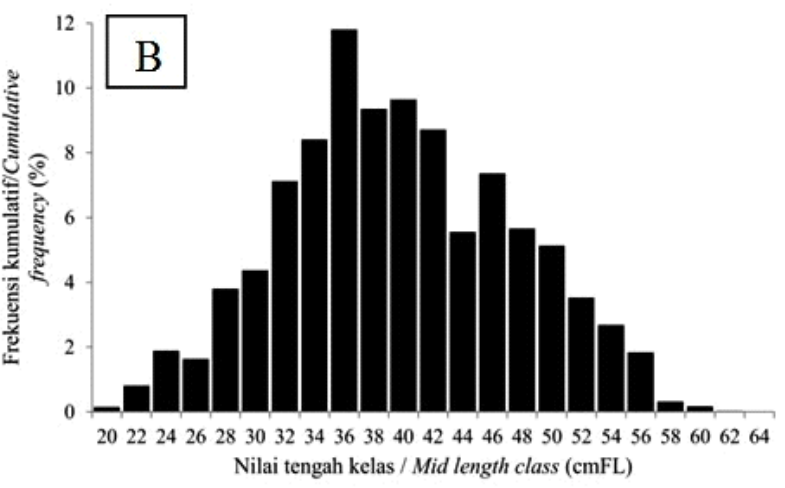

Gambar 4. Ukuran rata-rata tertangkap, $\mathrm{L}_{50 \%}$ (A) dan distribusi frekuensi panjang ikan cakalang (B) yang tertangkap di Samudera Hindia Barat Sumatera.

Figure 4. Average of fish length $\left(L_{50 \%}\right)(A)$, and length frequency distribution of skipjack $(B)$ caught in Indian Ocean West of Sumatera.
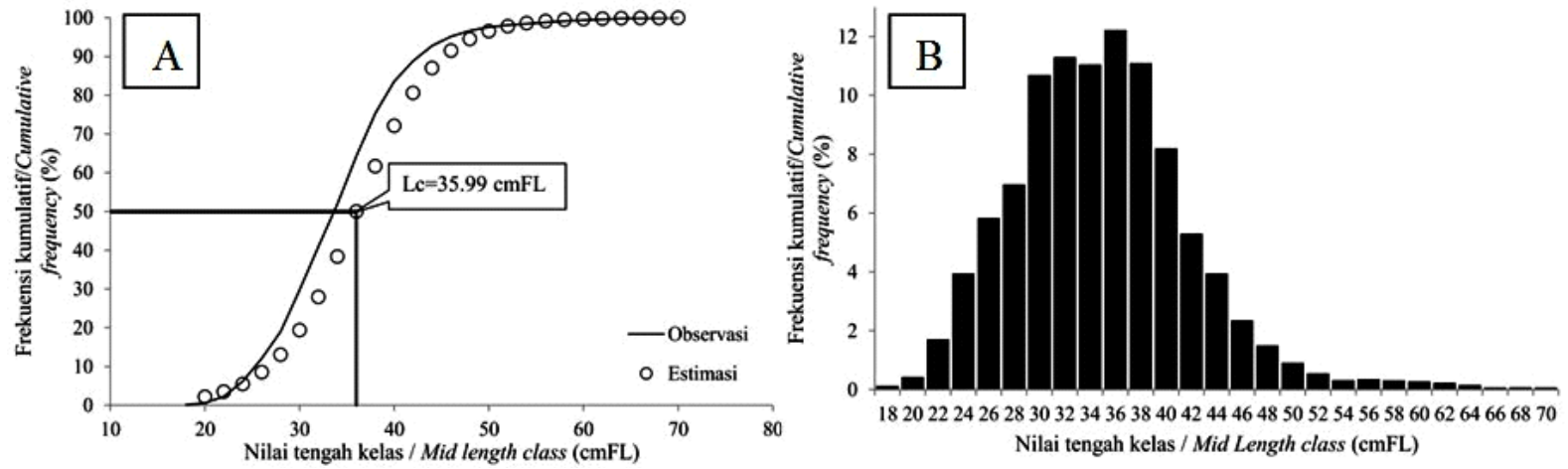

Gambar 5. Ukuran rata-rata tertangkap, $\mathrm{L}_{50 \%}$ (A) dan distribusi frekuensi panjang ikan cakalang (B) yang tertangkap di Samudera Hindia Selatan Jawa.

Figure 5. Average of fish length $\left(L_{50 \%}\right)(A)$, and length frequency distribution of skipjack $(B)$ caught in Indian Ocean South of Java.

Panjang rata-rata ikan cakalang tertangkap di WPP$573\left(\mathrm{~L}_{50 \%}\right)$ sebesar 39,40 cmFL (Gambar 4.), dan yang tertangkap di WPP-572 sebesar 35,99 cmFL (Gambar 5). Nilai L- ${ }_{\mathrm{c}}$ penting diketahui karena dapat dibandingkan dengan panjang ikan saat pertama kali matang gonad $\left(\mathrm{L}_{\mathrm{m}}\right)$ untuk keberlanjutan rekruitmen ikan cakalang. Struktur ukuran ikan cakalang yang tertangkap dengan pukat cincin di Barat Sumatera adalah lebih besar dari di Selatan Jawa (Tabel 1).

Tabel 1. Ringkasan data frekuensi panjang ikan cakalang di Samudra Hindia yang tertangkap pukat cincin Table 1. Summary length frequency data of skipjack tuna caught in the Indian Ocean using purse seine

\begin{tabular}{lcc}
\hline & WPP-573/ & WPP-572 / \\
& FMA-573 & FMA-572 \\
\hline Jumlah Sample (ekor) & 5.923 & 10.524 \\
L $_{\min }$ (cmFL) & 20 & 18 \\
L $_{\max }$ (cmFL) & 64 & 70 \\
L $_{\text {rerata }}$ (cmFL) & 39.2 & 34 \\
Panjang Dominan (cmFL) & $35-37$ & $34-36$ \\
L $_{50 \%}$ (cmFL) & 39,40 & 35.99 \\
\hline
\end{tabular}




\section{Parameter Pertumbuhan}

Hasil perhitungan dengan persamaan Von Bertalanffy yang dikombinasikan dengan rumus Pauly (1983) diperoleh estimasi $\mathrm{L}_{\infty}$ ikan cakalang di WPP-573 adalah 67,20 cmFL, $\mathrm{K}=0,27 /$ tahun, dan $\mathrm{t}_{\mathrm{o}}=-0,50$. Hasil perhitungan parameter pertumbuhan tersebut menghasilkan persamaan pertumbuhan $\mathrm{L}_{\mathrm{t}}=67,20\left(1-\mathrm{e}^{-0,27(\mathrm{t}+0,50)}\right)$. Ikan cakalang di

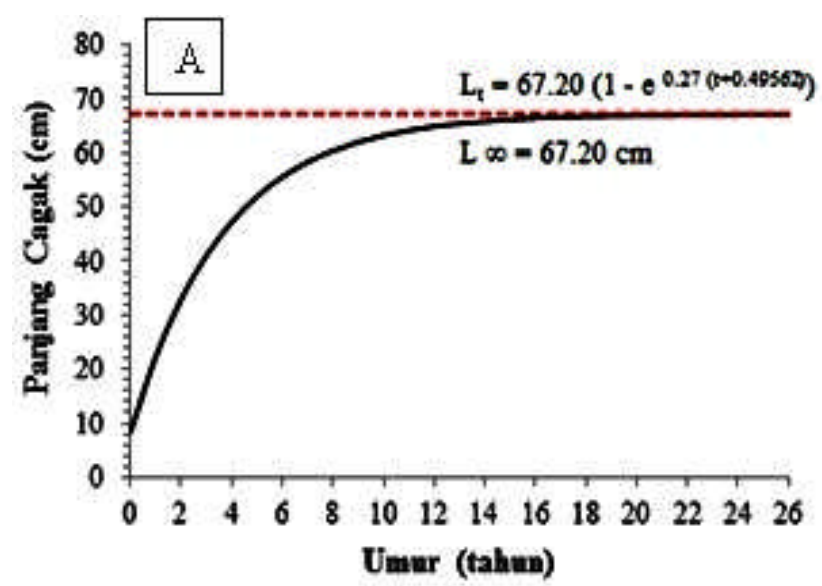

WPP-572 diperoleh persamaan pertumbuhan $\mathrm{Lt}=73,5(1-$ $\left.\mathrm{e}^{-0,22(\mathrm{t}-0,59)}\right)$. Dari kedua persamaan pertumbuhan tersebut, dapat dibuat kurva hubungan antara umur dengan panjang tubuh ikan cakalang. Kurva pertumbuhan ikan cakalang di WPP-573 dan 572 disajikan pada Gambar 6A dan 6B. Starting point dan starting length yang dipilih dan diterapkan dalam analisis menggunakan FiSAT adalah 8 dan $21 \mathrm{cmFL}$.

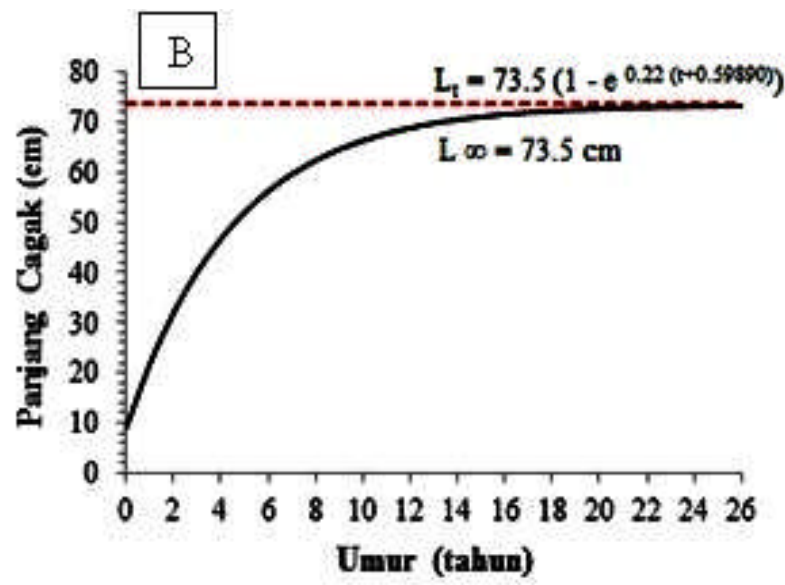

Gambar 6. Kurva pertumbuhan ikan cakalang di Samudra Hindia tahun 2016: (A) WPP-573 dan; (B) WPP-572.

Figure 6. Growth curve skipjack tuna caught in Indian Ocean: (A) FMA-573 and; (B) FMA-572.

\section{Mortalitas dan Laju Eksploitasi}

Nilai-nilai parameter populasi ikan cakalang digunakan sebagai bahan masukan untuk membuat kurva hasil tangkapan yang berfungsi untuk menduga mortalitas dan

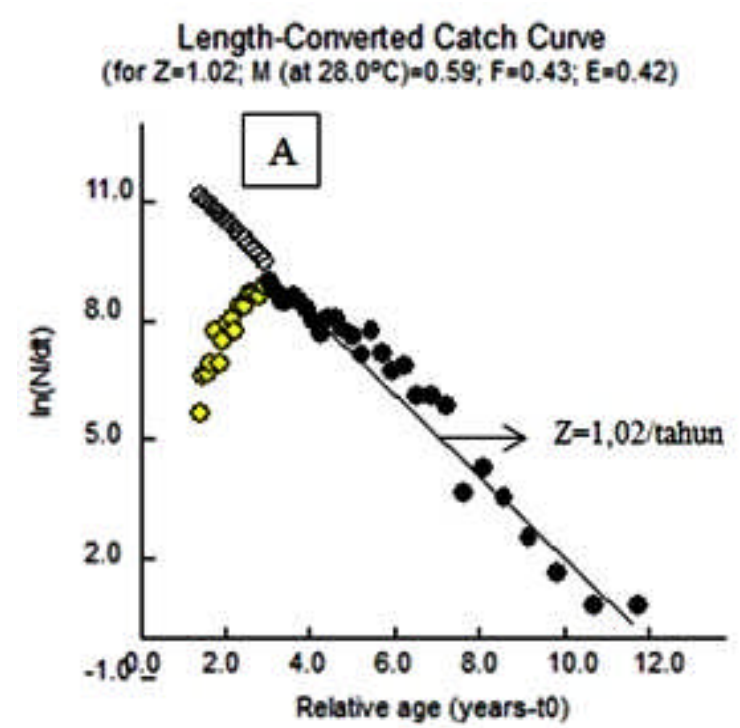

laju eksploitasi ikan cakalang di Samudra Hindia. Mortalitas untuk populasi ikan yang sudah tereksploitasi merupakan kombinasi antara mortalitas alami dan mortalitas karena penangkapan (Pauly, 1983; Sparre \&Venema, 1999; Welcomme, 2001).

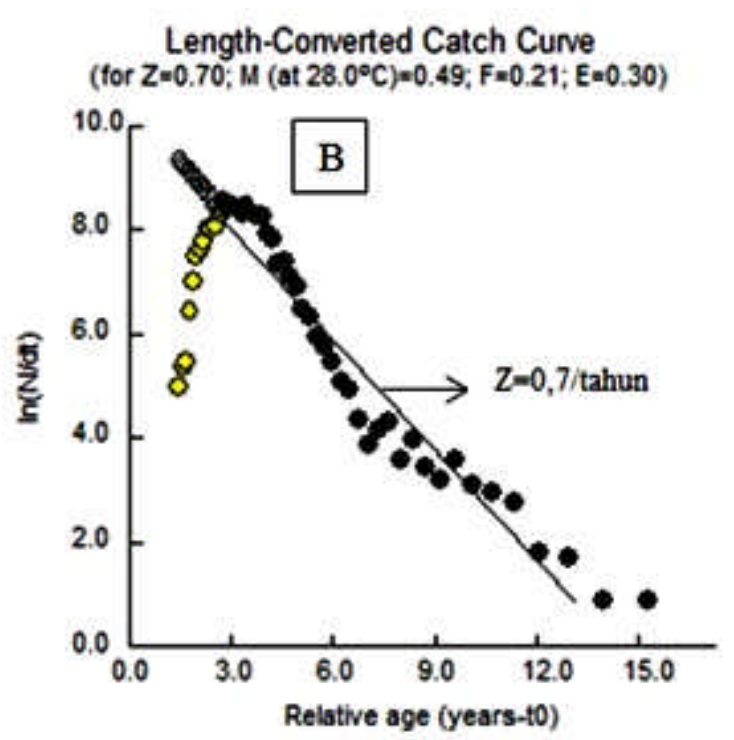

Gambar 7. Nilai Z sebagai slope kurva hasil tangkapan ikan cakalang di WPP-573 (A) dan WPP-572 (B). Figure 7. The value of $Z$ as slope of the catch curve of skipjack in FMA-573 (A) and FMA-572 (B).

Hasil perhitungan nilai $\mathrm{Z}$ dengan menggunakan plot length converted cacth curve ikan cakalang di WPP -573 adalah sebesar 1,02/tahun (Gambar 7A.) dan Z=0,7/tahun di WPP-572 (Gambar 7B). Berdasarkan hasil perhitungan diperoleh nilai E ikan cakalang di kedua perairan tesebut berturut-turut adalah 0,42 dan 0,30 (Tabel 2.). 
Tabel 2. Parameter pertumbuhan ikan cakalang di Samudra Hindia

Table 2. Growth parameters of skipjack tuna in Indian Ocean

\begin{tabular}{ccc}
\hline Parameter Populasi/ & WPP-573/ & WPP-572/ \\
Population Parameters & FMA -573 & FMA-572 \\
\hline L $_{\infty}$ (cmFL) & 67,20 & 73,5 \\
K (per tahun) & 0,27 & 0,22 \\
to $_{\text {(tahun})}$ (per tahun) & $-0,50$ & $-0,59$ \\
Z & 1,02 & 0,70 \\
M (per tahun) & 0,59 & 0,49 \\
F (per tahun) & 0,43 & 0,21 \\
E (per tahun) & 0,42 & 0,30 \\
\hline
\end{tabular}

\section{Pola Rekruitmen}

Hasil analisis dengan FiSAT menunjukkan pola rekruitment ikan cakalang di WPP 573 terditeksi terjadi dua kali dalam satu tahun dengan puncak tertinggi pada bulan April dan Mei (Gambar 8A). Sedangkan ikan cakalang di WPP-572 terjadi punca rekruitmen pada bulan
Maret dan September (Gambar 8B). Nilai punca rekruitmen di WPP-573 relatif lebih tinggi dibandingkan dengan WPP572 , yaitu $24,5 \%$ dibanding $17,5 \%$. Hasil pengamatan kelompok umur ikan cakalang menggunakan metode Bhattacharya menunjukkan bahwa terdapat kelompok ukuran kecil pada bulan Januari-Maret di WPP-572 (Tabel. 3) dan Juli Agustus di WPP-573 (Tabel. 4)
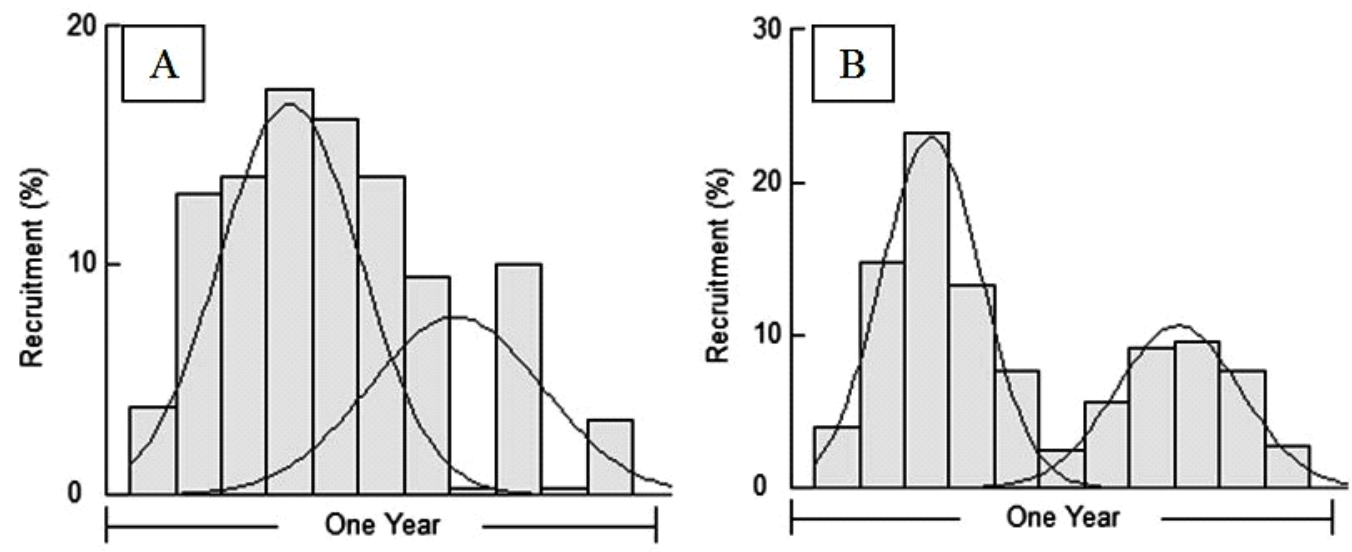

Gambar 8. Pola rekruitment ikan cakalang (K. pelamis) di Samudra Hindia: (A) WPP 573; (B) WPP 572.

Figure 8. Recruitment pattern of skipjack tuna in Indian Ocean: (A) FMA 573; (B) WPP 572.

Tabel 3. Kelompok ukuran ikan cakalang di Samudra Hindia WPP-572 berdasarkan metode Bhattacharya Table 3. The skipjack size group in the Indian Ocean FMA-572 by Bhattacharya method

\begin{tabular}{lccccc}
\hline \multirow{2}{*}{$\begin{array}{c}\text { Bulan/ } \\
\text { Month }\end{array}$} & \multirow{2}{*}{$\begin{array}{c}\text { Jumlah kelompok umur/ } \\
\text { number of age group }\end{array}$} & \multicolumn{4}{c}{$\begin{array}{c}\text { Panjang rata-rata individu perkelompok umur/ } \\
\text { individual length average by group }\end{array}$} \\
\cline { 3 - 6 } & & I & II & III & IV \\
\hline Januari & 4 & 28,9 & 38,3 & 47,5 & 60,8 \\
Februari & 3 & 26,3 & 37,6 & 61 & - \\
Maret & 2 & 26,7 & 45 & - & - \\
April & 2 & 23,8 & 30 & - & - \\
Mei & 2 & 33,7 & 51,5 & - & - \\
Juni & 2 & 36,1 & 51,1 & - & - \\
Juli & 4 & 25,5 & 36,8 & 47,8 & 62,3 \\
Agustus & 3 & 30 & 39,8 & 55 & - \\
September & 3 & 30 & 38,3 & 57,5 & - \\
Oktober & 2 & 30,2 & 43,7 & - & - \\
November & 3 & 33,9 & 42,4 & 66,8 & - \\
Desember & 3 & 33,8 & 41,2 & 65,2 & - \\
\hline
\end{tabular}


Tabel 4. Kelompok ukuran ikan cakalang di Samudra Hindia WPP-573 menggunakan metode Bhattacharya Table 4. The skipjack size group in the Indian Ocean FMA-573 by Bhattacharya method

\begin{tabular}{lccccc}
\hline \multirow{2}{*}{$\begin{array}{c}\text { Bulan/ } \\
\text { Month }\end{array}$} & $\begin{array}{c}\text { Jumlah kelompok umur/ } \\
\text { number of age group }\end{array}$ & \multicolumn{4}{c}{$\begin{array}{c}\text { Panjang rata-rata individu perkelompok umur/ } \\
\text { individual length average by group }\end{array}$} \\
\cline { 3 - 6 } & & $\mathrm{I}$ & $\mathrm{II}$ & $\mathrm{III}$ & $\mathrm{IV}$ \\
\hline Januari & 2 & 35,32 & 47,45 & - & - \\
Februari & 2 & 34,73 & 44,06 & - & - \\
Maret & 2 & 38,78 & 49,98 & - & - \\
April & 2 & 40,23 & 53,94 & - & - \\
Mei & 3 & 34,18 & 42,09 & 51,86 & - \\
Juni & 4 & 26 & 35,45 & 41,82 & 50,73 \\
Juli & 2 & 24,17 & 34,22 & - & - \\
Agustus & 3 & 24 & 35,38 & 54,46 & - \\
September & 2 & 32,25 & 41,57 & - & - \\
Oktober & 1 & 35,07 & - & - & - \\
November & 3 & 28,11 & 36,79 & 43,48 & - \\
Desember & 2 & 30,39 & 37,92 & - & - \\
\hline
\end{tabular}

\section{Bahasan}

Panjang terkecil, terbesar dan panjang rata-rata ikan cakalang yang tertangkap di WPP 573 adalah $20 \mathrm{~cm}, 63$ $\mathrm{cm}$, dan 39,2 cmFL; panjang dominan pada kelas panjang 35-37 cmFL (Tabel 1), Sedangkan di WPP 572 panjang terkecil, terbesar, dan rata-rata masing-masing $18 \mathrm{~cm}, 70$ $\mathrm{cm}$, dan $34 \mathrm{cmFL}$; panjang dominan pada kelas panjang 34-36 cmFL (Tabel 1).

Penelitian Fadhilah (2010) memperoleh panjang total ikan cakalang yang didaratkan di Palabuhanratu berkisar antara 24,6-53,5 cm. Menurut Mayangsoka (2010) panjang ikan cakalang yang tertangkap di Samudra Hindia Barat bekisar antara 25-56,8 cmFL; frekuensi tertinggi (modus) terdapat pada selang kelas 32,4-37,5 cmFL, selanjutnya Mallawa et al. (2014) memperoleh panjang terkecil, terbesar dan panjang rata-rata ikan cakalang yang tertangkap pukat cincin di Laut Flores sebesar 17,5 cm, 69,5 cm dan 37,2 cmFL; panjang dominan (modus) pada kisaran panjang 24 $-29 \mathrm{~cm}$ FL dan 49,5 - 54,5 cm FL, di hasil lain, Baso (2013) menyatakan ikan cakalang yang tertangkap huhate di Teluk Bone memiliki panjang total antara $14,0-86,0 \mathrm{~cm}$, dengan frekuensi tertinggi pada kelas panjang $26,0-29,0 \mathrm{~cm}(\mathrm{n}=132$ ekor) dan $83,0-86,0 \mathrm{~cm}$ ( $\mathrm{n}=7$ ekor). Ikan cakalang di Teluk Bone dapat mencapai panjang total $86,0 \mathrm{~cm}$.

Panjang rata-rata ikan cakalang pada penelitian ini sekitar 39,40 cmFL di WPP-573 dan 35,99 cmFL di WPP572. Perbedaan panjang ini dipengaruhi oleh alat tangkap yang digunakan. Selektivitas alat tangkap dapat dijadikan salah satu pilihan dalam mengatur ukuran yang layak untuk ditangkap. Ikan yang layak tangkap hendaknya merupakan ikan-ikan yang setidaknya telah melakukan pemijahan/ matang gonad. Banyaknya ikan-ikan muda yang tertangkap akan beresiko terhadap keseimbangan stok ikan. Berdasarkan penelitian Jatmiko et al. (2015) panjang pertama kali matang gonad (Lm) cakalang di Samudra Hindia bagian timur adalah $42,9 \mathrm{~cm}$ dengan kisaran panjang antara 41,6-44,3 cm. nilai Lm ikan cakalang pada periode ini adalah 38,8 cmFL (Anonimus, 2016). Ikan cakalang memijah pada ukuran 40-45 cm dengan umur kurang lebih satu tahun (Rochman et al, 2015). Berdasarkan penelitianpenelitian sebelumnya, ikan cakalang yang ditangkap menggunakan alat tangap pukat cincin berukuran dibawah panjang pertama kali matang gonad.

Struktur panjang ikan cakalang pada Gambar 2 dan 3 menggambarkan masing-masing populasi ikan cakalang di Samudra Hindia Selatan Jawa dan Barat Sumatra terdiri dari 1-4 kelompok umur (kohort). Perbedaan kelompok umur dalam suatu populasi ikan menggambarkan bahwa ikanikan yang tertangkap terdiri dari ikan muda dan dewasa (Nasution, 2009). Hal yang membatasi suatu struktur umur dalam suatu populasi ikan salah satunya adalah mortalitas pada populasi tersebut. Suatu populasi ikan dianggap stabil apabila terdapat banyak struktur umur didalamnya (Effendie, 2002).

Berdasarkan penelitian ini diketahui bahwa panjang ikan cakalang pada umur satu tahun kurang lebih $37 \mathrm{~cm}$, pada tahun kedua dapat mencapai $46 \mathrm{~cm}$, tahun ketiga 55 $\mathrm{cm}$, tahun ke empat $64 \mathrm{~cm}$, tahun kelima $72 \mathrm{~cm}$, bahkan cakalang dapat mencapai 1 meter pada umur lebih dari 7 tahun dengan berat diperkirakan $25 \mathrm{~kg}$. Pada umumnya ikan cakalang yang tertangkap berukuran panjang 40-60 $\mathrm{cm}$. Ikan cakalang yang berada di permukaan perairan adalah cakalang kecil (kurang dari 4 kg/ekor) sedangkan cakalang besar lebih dari $6,5 \mathrm{~kg} / \mathrm{ekor}$ biasanya di lapisan perbatasan termoklin dan beradaptasi dengan perairan yang sejuk (Toatubun, 2015). 
Panjang asimtotik $\left(\mathrm{L}_{\infty}\right)$ ikan cakalang di WPP-573 adalah 66,15 cmFL (Gambar 6) dan di WPP-572 adalah 70,35 cmFL (Gambar 7). Nilai $\mathrm{L}_{\infty}$ ikan cakalang yang diperoleh ini pada umumnya lebih kecil jika dibandingkan dengan hasil penelitian sebelumnya di beberapa perairan. Rochman et al. (2015) menyatakan bahwa ikan cakalang yang di eksploitasi di Samudra Hindia dengan berbagai macam alat tangkap seperti pukat cincin, jaring insang, rawai tuna, dan pancing ulur dan didaratkan di Cilacap, Palabuhanratu, Pacitan dan Sendang Biru memiliki nilai $\mathrm{L}_{\infty}$ yang relatif besar yaitu $80.85 \mathrm{cmFL}$. Sedangkan ikan cakalang di daerah lain seperti Laut Flores Timur memiliki nilai sebesar $100 \mathrm{cmFL}$. Perbedaan nilai $\left(\mathrm{L}_{\infty}\right)$ selain di pengaruhi oleh kondisi perairan juga dipengaruhi oleh alat tangkap dan selektivitas alat tangkap tersebut.

Nilai koefisien pertumbuhan (K) adalah nilai yang menunjukkan kecepatan suatu jenis ikan dalam mencapai panjang asimtotiknya (Toatubun, 2015). Semakin besar nilai K maka semakin cepat pula laju pertumbuhan ikan atau semakin pendek pula umur ikan tersebut (Nasution, 2009). Berdasarkan hasil perhitungan, nilai K ikan cakalang yang diperoleh di WPP-573 dan 572 cincin adalah 0.27/ tahun dan 0.22/tahun. Perbedaan parameter pertumbuhan disebabkan perbedaan lama waktu, musim, panjang ikan, alat tangkap yang digunakan dan daerah penangkapan pada saat sampling. Perbedaan nilai parameter populasi disebabkan adanya perbedaan kondisi perairan dan ketersediaan pakan di perairan tempat ikan tumbuh dan berkembang, perbedaan tersebut dapat dilihat melalui hasil-hasil penelitian sebelumnya pada ikan cakalang (Tabel 5).

Umur teoritis ikan pada saat panjang sama dengan nol $\left(\mathrm{t}_{\mathrm{o}}\right)$ adalah parameter umur di awal populasi ikan. Nilai $\mathrm{t}_{\mathrm{o}}$ merupakan hasil dari perhitungan antara nilai $\mathrm{L}_{\infty}$ dan $\mathrm{K}$ (Pauly, 1983). Umur teoritis ikan cakalang di WPP-573 dan 572 adalah 0,50 dan 0,59 .

Tabel 5. Perbandingan parameter populasi ikan cakalang di beberapa lokasi

Table 5. Comparison of skipjack population parameters in some location

\begin{tabular}{lllll}
\hline \multicolumn{1}{c}{$\begin{array}{c}\text { Sumber/ } \\
\text { Sources }\end{array}$} & \multicolumn{1}{c}{\begin{tabular}{c}
\multicolumn{1}{c}{ Lokasi/ } \\
Locations
\end{tabular}} & \multicolumn{1}{c}{ Lo $_{\infty}$} & \multicolumn{1}{c}{ K } & \multicolumn{1}{c}{$\mathbf{t}_{\text {o }}$} \\
\hline Mayangsoka (2010) & Samudra Hindia (Barat Sumatra) & 59,12 & 0,4 & $-1,07$ \\
Fadhilah(2010) & Samudra Hindia (Selatan Jawa) & 66,2 & 0,2 & $-0,66$ \\
Koya et al. (2012) & Samudra Hindia & 92 & 0,5 & $-0,0012$ \\
Gaertner et al. (2008) & Samudra Atlantik & 89,38 & 0,4 & $-0,17$ \\
Jamal et al. (2012) & Perairan Teluk Bone & 75,9 & 0,2 & $-0,36$ \\
Penelitian ini & Samudra Hindia WPP 573 & 67,20 & 0,27 & $-0,50$ \\
\hline
\end{tabular}

Pengurangan stok ikan dalam suatu populasi disebabkan oleh jumlah kematian alami (M) dan jumlah kematian akibat aktivitas penangkapan (F). Dari hal tersebut dapat dipahami bahwa tingkat eksploitasi (E) suatu populasi ikan merupakan pembagian/perbandingan antara mortalitas akibat penangkapan dengan kematian total (Z) (Pauly, 1983). Laju eksploitasi optimum terjadi jika terdapat keseimbangan rasio antara $\mathrm{M}$ dan $\mathrm{F}$, sehingga diasumsikan bahwa nilai eksploitasi optimum (E) yang lestari setara dengan $\mathrm{E}=0,50$ (Gulland, 1971). ).

Tabel 2 (Benar Disini Penyimpananya) menyajikan informasi mengenai tingkat mortalitas dan tingkat ekspoitasi ikan cakalang di Samudra Hindia; diperoleh bahwa tingkat kematian ikan cakalang akibat penangkapan di WPP-573 hampir sama dengan kematian alaminya, sedangkan di WPP-572 tingkat kematian ikan cakalang akibat penangkapan masih lebih rendah dibandingkan dengan kematian alamiahnya. Penentuan nilai laju eksploitasi merupakan salah satu faktor yang perlu diketahui untuk mengetahui kondisi sumberdaya perikanan dalam pengkajian stok ikan (King, 1995). Dilihat dari nilai E di WPP-573 sebesar 0,42/tahun, dan 0,30 di
WPP-573 dapat disimpulkan bahwa tekanan eksploitasi cakalang di Samudra Hindia masih dibawah nilai optimum.

Pola rekruitmen cakalang di WPP-572 dan 573 menunjukkan terdapatnya 2 kelompok umur dalam satu tahun. Kelompok umur cakalang di WPP 573 terjadi tumpang tindih yaitu pada bulan April dan Sepember. Sedangkan pada WPP-572 pola recruitment terlihat lebih jelas dan rekruitmen tertinggi terjadi pada bulan FebruariMaret dan diduga setelah bulan Agustus (Tabel. 4) Secara umum persentase rekruitmen di WPP-572 lebih besar di bandingkan dengan 573 yaitu 23\%. Puncak rekrutmen ikan cakalang terjadi pada bulan April (10,42\%) dan Agustus $(20,06 \%)$. Hal itu diduga akibat bergesernya musim pemijahan ikan cakalang yang ditandai dengan kemunculan individu baru dari hasil pemijahan pada bulan Oktober (Rochman et al., 2015).

\section{KESIMPULAN}

Struktur ukuran dan panjang rata-rata tertangkap ikan cakalang (Katsuwonus pelamis) dari alat tangkap pukat cincin cenderung lebih kecil dibandingkan alat tangkap 
lainnya. Nilai parameter populasi $\left(\mathrm{L}_{\infty}, \mathrm{K}, \mathrm{t}_{\mathrm{o}}\right.$, ) yang diperoleh di WPP-573 berturut-turut adalah $67.20 \mathrm{cmFL}, 0,27 /$ tahun, dan $-0,50$ tahun. Nilai-nilai parameter populasi di WPP572 adalah 73,5 cmFL, 0,22/tahun, dan -0,59 tahun. Ikan cakalang yang tertangkap di Samudra Hindia Selatan Jawa menunjukan tekanan penangkapan lebih tinggi dibandingkan dengan Barat Sumatra karena tingkat kematian akibat penangkapannya lebih tinggi. Secara umum laju eksploitasi ikan cakalang di Selatan Jawa dan Barat Sumatra masih di bawah tingkat pemanfaatan optimum $(E=0.5)$. pola rekruitmen cakalang di WPP-573 terjadi pad bulan April dan September, sedangkan pola rekruitmen cakalang di WPP-572 terjadi pada bulan Maret dan Agustus.

\section{PERSANTUNAN}

Tulisan ini merupakan bagian dari hasil riset "Struktur dan Karaktersitik Perikanan Pukat Cincin di Samudra Hindia Untuk Menunjang Perikanan Laut Lepas di Wilayah RFMO" pada Loka Penelitian Perikanan Tuna (LP2T) tahun 2016. Penulis mengucapkan banyak terimakasih kepada enumerator daerah yang bekerjasama dengan LP2T yang telah membantu dalam pengumpulan data.

\section{DAFTAR PUSTAKA}

Anonimus. (2012). Riset Karakteristik Perikanan Tuna di Samudra Hindia. Laporan Akhir. Loka Penelitian Perikanan Tuna. Pusat Penelitian Pengelolaan Perikanan dan Konservasi Sumberdaya Ikan. Balitbang KP.

Anonimus. (2015). Keputusan Menteri Kelautan Dan Perikanan Republik Indonesia Nomor 107/Kepmen-Kp/ 2015 Tentang Pengelolaan Perikanan Tuna, Tongkol Dan Cakalang.

Anonimus. (2016). Loka Riset Perikanan Tuna. Laporan Akhir. Loka Riset Perikanan Tuna. Pusat Riset Perikanan KP. BRSDM KP.

Baso, H., (2013). Kajian biologi populasi ikan cakalang (Katsuwonus pelamis) di perairan Luwu Teluk Bone. Tesis, PPs UnHas. Makassar. p. 123.

Effendie, M. I. (2002). Biologi Perikanan (p. 163). Yogyakarta:. Penerbit Yayasan Pustaka Nusatama

Fadhilah, L. N. (2010). Pendugaan pertumbuhan dan mortalitas ikan cakalang (Katsuwonus pelamis Linnaeus, 1758) yang didaratkan di PPN Palabuhanratu, Kabupaten Sukabumi, Provinsi Jawa Barat. skripsi. Bogor (ID): Institut Pertanian Bogor.
Gaertner, D., Molina, A. D., Ariz, J., Pianet, R. \& Hallier, J. P. (2008). Variability of the growth parameters of the skipjack tuna (Katsuwonus pelamis) among areas in the eastern Atlantic: analysis from tagging data within a meta-analysis approach. Journal Aquatic Living Resources. 21.349-356.

Gayanilo, F. C. Jr., Sparre, P. \& Pauly, D. (2005). FAOICLARM stock assessment tool II (FiSAT II). Revised version. User's guide. FAO Computerized Information Series. (Fisheries). No.8. (p. 168) Revised version. FAO: Rome.

Gulland, J. A. (1971). The Fish Resources of the Oceans. (p. 255). FAO Fishing News (Books) Ltd. Surrey. 255p.

Hariati, T. \& Amri, K. (2011). Perkembangan perikanan pelagis kecil hasil tangkapan pukat cincin dan bagan di perairan Barat Sumatra. J.Lit.Perik.Ind. 17 (4), 230235

ISSF. (2015). ISSF Tuna Stock Status Update 2015: Status of the world fisheries for tuna. ISSF Technical Report 2015-03. International Seafood Sustainability Foundation, Washington, D.C., USA.

Jamal, M., Sondita, M. F A., Haluan, J. \& Wiryawan, B. (2011). Pemanfaatan data biologi ikan cakalang (Katsuwonus pelamis) dalam rangka pengelolaan perikanan bertanggung jawab di perairan Teluk Bone. Jurnal Natur Indonesia 14(1), 107-113.

Jatmiko, I., Hartaty, H. \& Bahtiar, A. (2015). Biologi reproduksi ikan cakalang (Katsuowonus pelamis) di Samudra Hindia Bagian Timur. BAWAL: 7(2), 87-94.

King M. 1995. Fishery Biology, Asessment, And Management. (p. 341) London, USA: Fishing News Books.

Koya, K. P. S., Joshi, K. K., Abdussamad, E. M., Rohit, P., Sivadas, M., Kuriakose, S., Ghosh, S., Koya, M., Dhokia, H. K., Prakasan, D., Koya, V. A. K. \& Sebastine, M. (2012). Fishery, biology and stock structure of skipjack tuna, Katsuwonus pelamis (Linnaeus, 1758) exploited from Indian waters. Indian Journal Fish. 59(2), $39-47$.

Mallawa, A., Amir, F. \& Zainuddin, M. (2014). Keragaan biologi populasi ikan cakalang (Katsuwonus pelamis) yang tertangkap dengan purse seine pada musim timur di perairan laut Flores. Jurnal IPTEKS PSP. 1(2), 129145. 
Mayangsoka, Z. A. (2010). Aspek biologi dan analisis ketidakpastian perikanan cakalang (Katsuwonus pelamis) yang didaratkan di PPS Nizam Zachman Jakarta. skripsi. Bogor: Institut Pertanian Bogor.

Nasution, S. H. (2009). Kajian dinamika populasi sebagai dasar pengelolaan ikan bonto-bonti (Paratherina striata) endemik di danau towuti, Sulawesi Selatan. Prosiding Seminar Nasional Forum Perairan Umum Indonesia VI, Palembang 18 November 2009. Balai Riset Perikanan Perairan Umum, Palembang: MSP 35 - 44.

Pauly, D. (1983). Some simple methods for the assessment of tropical fish stocks. FAO Fisheries Technical Paper. (254). 52p.

Rochman, F., Nugraha, B. \& Wujdi, A. (2015). Pendugaan parameter populasi ikan cakalang (Katsuwonus Pelamis, Linnaeus, 1750) di Samudra Hindia Selatan Jawa. BAWAL. 7(2), 77-85
Sparre, P. \& Venema, S. (1999). Introduction to tropical fish stock assesment. (Introduksi Pengkajian Stok Ikan Tropis, alih bahasa: Pusat Penelitian dan Pengembangan Perikanan). Buku 1: Manual. (p. 438) Jakarta: Badan Penelitian dan Pengembangan Perikanan.

Toatubun, N., Wenno, J. \& Labaro, I.J. (2015). Struktur Populasi Ikan Cakalang Hasil Tangkapan Pukat Cincin yang Didaratkan di Pelabuhan Perikanan Pantai Tumumpa Kota Manado. Jurnal Ilmu dan Teknologi Perikanan Tangkap. 2(2), 73-77.

Welcomme, R. L. (2001). Inland Fisheries: Ecology and Management. (p. 358) London Fishing News Book. A Division of Blackwell Science

Wibowo, S., Suryanto., \& Nugroho, D. (2016). Karakteristik upaya dan daerah penangkapan pukat cincin pelagis besar yang berpangkalan di PPS Bitung. J.Lit.Perik.Ind.. 22(1), 51-60. 